\title{
THE MARK OF THE KNIFE: \\ SCARS AS SIGNS IN BORGES
}

imase paciente laberinto de lineas traza la
imagen de su cara.

(Bcrges) $)^{1}$

$\ldots$ ifone wanes to call this inseription in naked flesh 'writing', then it must be sidid Wat speech in lact presupposes writing, and that it is this cruel system of inseribed signs that renders man capabli: of language, and gives him a memory of the spuken word.

\section{(Deleuze and Guattarij2}

te the close of a long conversation with Borges about his favourite Victorian and Edwardian writers - Stevenson, Kipling, C'hesterton, Niells, and others - the doorbell rang and the next visitor, a young Paraguayan writer, was shown in. Borges, hearing the nationality of the newcomer, asked me: 'Do you remember the dictator of Paraguay?' Not sure which one he was referring to, I ventured: 'Stroessner? Doctor Francia?' 'No, no', said Borges; the one with the scar'. Obviously he was not speaking of a historical figure, but was still discussing licerature. The Paraguayan dictator he was referring to was John Vandelicur in Stevenson's New Arabian Nights, an Englishman who is described in The Rajah's Dumond as 'the biggest adventurer, the best judge of precious stonces, and one of the most acute diplomatists in Europe', known for his 'expluits and atrocities when he was Dictator of Paraguay'. Stcevenson describes him thus:

Old Juhn V'andeleur was of remarkable force of body. . . H His leat lures were buld and .upuiline; his expression arrogant and predatory; his whole appearance hat of a swilt, videter,

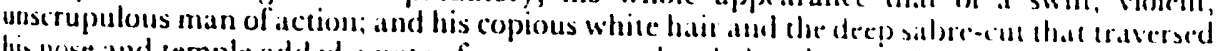

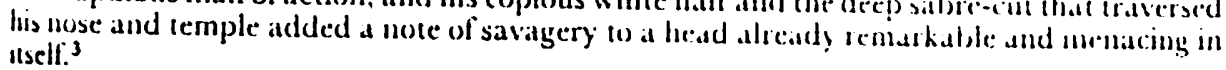

This description corroborates another character's assertion in Stevenson's novella that Vandeleur has prodigious claims to both fane and inlimy. ${ }^{4}$

Borges had been blind for many years at the time of this conversation and lived in d world of books he remembered with eerie precision. His question about the Paraguayan dictator was disconcerting because: he fitiled to make clear that he was thinking of a fictional rather than a historical dictator. It reveals how fiscinated Borges, perhaps the most bookish writer who ever lived, telt by the world of ams and violence. In retrospect, however, the most revealing dspect of the guestion is the detail that Borges found so striking and so unmistikable about this particular dictator of Paraguay: the scar that crossed his nose and tempte. Stevenson never tells

\footnotetext{
'Jurge Luis Borges, Obras completas (Buenos Aires, $197+1$, p. Hj. . Licept where wherwise nultal, all

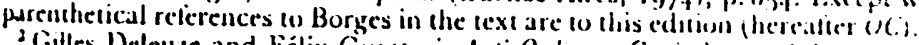

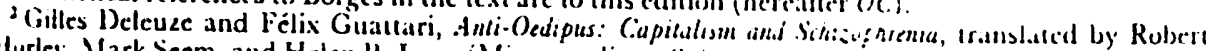
Hurler, Mark Seem, and Helen K. Lane (Minneapulis, 1,y 83$), 1.1+5$.

'Rubert Louis Stevenson, Ilorks, edited by Charles Curris Bigelow and Temple Siont, Io wols (New

liork, 1900), 1, 115.

'Sicienson, l, 114.
} 
the story of Vandelcur's scar, but it is the ultimate proof of his violent and adventurous past, and serves to caution both characters and readers to be suspicious of the former dictator. It is not surprising that Borges, blind reader and rereader of a world of literature that lived in his memory, should have had a special place for Vandeleur in his gallery of scoundrels.

$V$ andeleur's scar is both repulsive and fascinating, as scars often are in literature and the visual arts (and, for that matter, in real life). As a visual image, his aquiline face, marked by a long lateral sabre cut, is striking; as the initial image of a character in a story, the description is notable for its economy, since the scar acts for the reader as sign of past and future violence. The scar is also, at least initially, an ambiguous sign: it suggests violence but does not clarify whether Vandeleur acquired it when acting in a heroic or in a treacherous manner: whether, in a word, it needs to be read as a sign of fame or infany. Indeed, since Stevenson never tells its story, it can be considered a sort of thoating signifier throughout the novella.

landeleur's scar, then, is a sign of unpredictable violence which constantly threatens to crupt again, to envelop the whole of the story. The scar-sign derives further power in the story from its alliance with a linguistic sign which - for Sievenson's original readers as for us - cannot but signify violent conflict: Paraguaty. The former dictator, the missing link in a history which runs from Gaspar Redriguez de Francia to Alfredo Stroessner, though once the authoritative user of a languate of power, is now consigned by the instability of that power to the oblivion of history. His scar is a sign of his passage through history, indeed the only sign of that passage. Instead of putting his mark on the history of Paraguaty, he has been marked by it. The permanence and emblematic character of that mark, hough, do not sere to clarify the meaning of Vandeleur's past: the scar's unspecitied origin suggests the ambiguous and unstable nature of his participation in a more public stury.

Siars hate a rich and far-reaching iconographic history, from ancient times chrough Dante and Hawhorne we Sevenson, Borges, and beyond. Even though a complete catalogue ol scars in litcrature is impessible, it is important to note that lacial scars (significant because they are visible) have functioned as signs with vatiens meanings. In addition we the physical scar indicative of past heroism or villany, sears have also becon imposed by divine mandate, as in the mark of Cain,

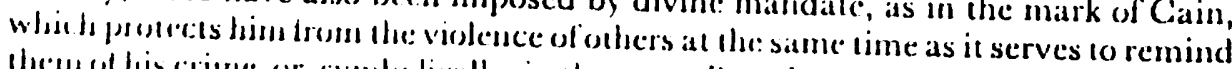
He'mol his crime, or, symbolically, in the seven Ps on Dante's brow in the Purgatorio, signily wh the seven deadly sins. Societies have marked or mutilated transgressors as a fmonslument and as at means 10 assure their identity. Cervantes refers to this

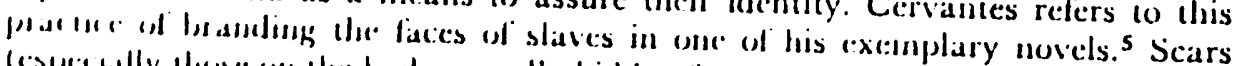

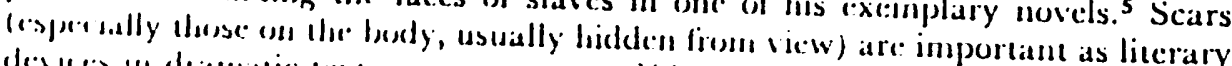

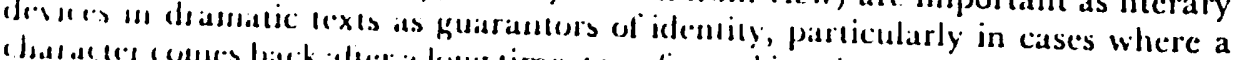

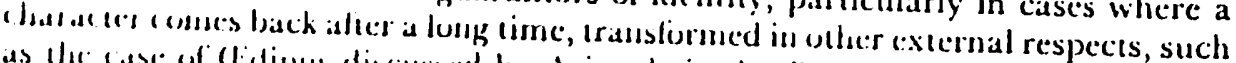
as the case of (lidipus discussed by Arisceste: in the Puetics. But scars may hatec a furtlare vintue in nasrative fiction: they croke an conigmat in the chatracter's past

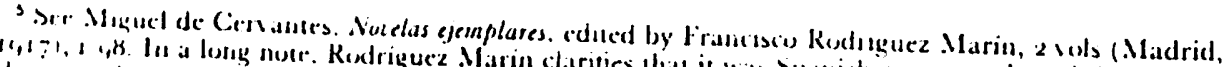

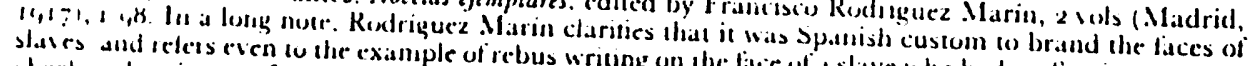

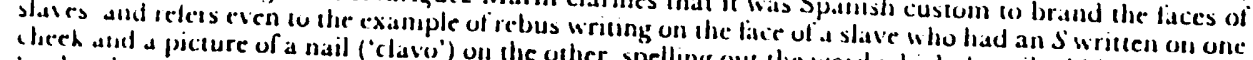
'heeh athd a picture of a nail ('clavo') on the other, spelling out the word which described his condition,
erse lavi". which can be resolved only by the telling of a story, usually a violent one, in which the scar constitutes the inscription of that story on the character's body and on the
body of the text.

A key to Borges's use of the scar as literary image is found in one of his essay's on description in narrative. In this essay he ridicules those writers who catalogue the assorted parts of a body and articles of clothing and expect their readers io be able to construct a unified whole from these diverse parts. He salys that the patching of lips of a particular kind to checks and nose is an impossible operation for the mind is perform. ${ }^{6}$ It is better, he suggests, 10 introducie only such elements ats are necessary for the reader to visualize the character in action, or details which by their anomalous nature force the reader to invent circumstances to justify their presence. Borges's ideas on narrative description are closely relat ced to Sicvenson's theory of
uarrative. 7 In an early essay on verisinilitude, narrative. ${ }^{7}$ In an early essay on verisimilitude, 'La postulación de lat realidad' (1929), Borges gives interesting examples of what he calls 'circumstantial details', Iermed 'circumstantial' because they evoke images not only of themselves but of contexts extraneous to the images themselves. He gives several examples of such details which suggest stories not told in the text. For instance, in an Argentine historical novel, Enrique Larreta's La gloria de don Ramiro, Borges points to an image of covers for soup pots secured with locks $(O C ;$; p. 220). The locks that protect the soup from the hungry servants not only serve to describe the pots but alsotedl us at

Borges labels the 'circumstantial details' as 'de larga proyeccion' $(O(2, p), 221)$, an idea derived from Stevenson's essaty 'A Gossip on Romance', his most important discussion of the theory of narrative. Stevenson uses as an exanple a seal story in which the discovery of some coins comes to him as reader like a surprise I had expected; whole vistas of secondary stories, besides the one in hand, radiated liurth trom that discovery, as they radiate from a striking particular in life's 'These 'secondary stories' are, of course, imagined by the reader, be bing only subly implied in the ext, but the invention of them is part of an open, playviul reading, one which fixes especially on the stories not told in the one that is. For Stevensen, then, the coins in the sea story were 'of long projection', as they sent his imagination travelling off after the implied stories, just as the 'circumstantial details' of the soup pots fior
Borges suggested stories of hunger and need."

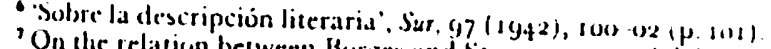

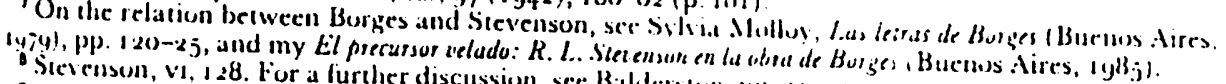

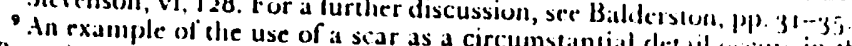

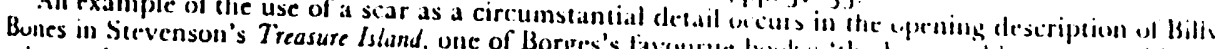

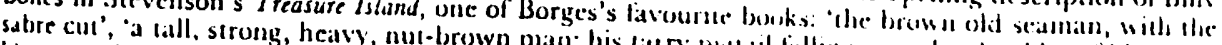

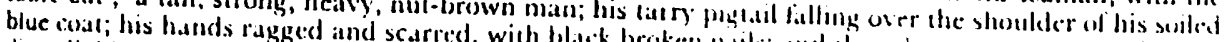

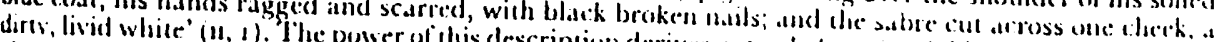

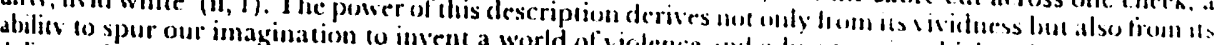

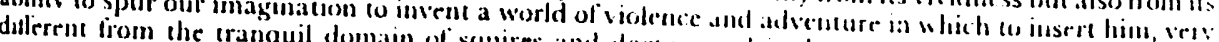
included in the parenthesis of the double reteres and doctors and innkerepers the entite description is

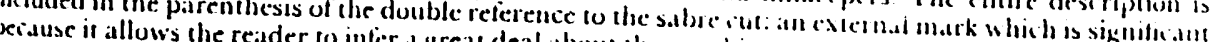

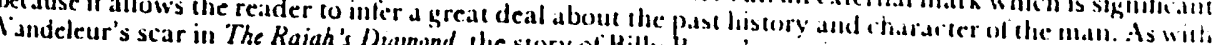

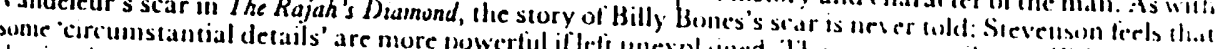

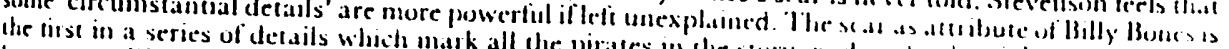

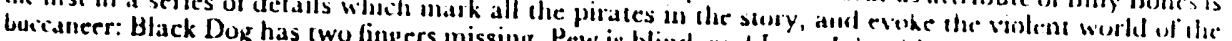


The first of Borges's stories to hinge on a scar ${ }^{10}$ is 'El incivil Maestro de Ceremonias Kotsuké no Suké', in Historia universal de la infamia, a series of biographies of scoundrels retold from various sources, published in book form in 1935 . The story of Kotsuké no Suké and the forty-seven Ronins is retold from A. B.F. Mitford's Tales of Old Japan. In Mitford's version Kotsuké no Suké insulted his visitor, Takumi no Kami, who became so enraged that he drew his short sword and 'aimed a blow at his head; but [since] Kotsuké no Suké [was] protected by the Court cap which he wore, the wound was but a scratch, so he ran away'. ${ }^{11}$ For this breach of courtly rules Takumi no Kami is arrested and obliged to commit hara-kiri. Years later, his forty-seven retainers discover Kotsuké no Suké in the palace and pursue him until they find him cowering in a closet: 'Oishoi Kuranosuké, bringing a lantern, scanned the old man's features, and it was indeed Kotsuké no Suké; and if further proof were wanting, he still bore a scar on his forehead where their master, Asano Takumi no Kami, had wounded him during the affray in the castle' (Mitford, p. 16). When their prisoner refuses to commit hara-kiri they kill him, then kill themselves for having committed murder.

Borges's version subtly stresses the scar, making the story hinge on this mark of Kotsuké no Suké's cowardice and treachery. Takumi no Kami, the Lord of the Tower of Ako, wounds Kotsuké no Suké on the forehead: 'El otro huyó, apenas rubricada la frente por un hilo tenue de sangre' $(O C$, p. 321$)$. The word rubricado signed or initialled with someone's rubric or signature - is highly charged here as elsewhere in Borges's work, since it serves to link the realms of arms and letters, making elear the relation Borges perceived between the knife and the pen. ${ }^{12}$ In the recognition scene, separately entitled 'La cicatriz', Kotsuké no Suké is found hiding not in a closet but behind a bronze mirror: 'Una espada temblorosa estaba en su diestra. Cuando bajaron, el hombre se entregó sin pelear. Le rayaba la frente una cicatriz: vicjo dibujo del acero de Takumi no Kami' $(O C$, p. 322$)$.

In the conclusion of the story Borges projects the meaning of the scar onto future generations and onto his readers. Mitford's tale ends with a bloody sequel: in 1868 an indigent warrior committed hara-kiri on the grave of the forty-seven Ronins, 'at about two hundred yards from my house, and when I saw the spot an hour or two later, the ground was all bespattered with blood, and disturbed by the deathstruggles of the man' (p. 24). Borges ends the story with the idea that the sequel is the retelling of the story itself: 'Este es el final de la historia de los cuarenta y siete hombres leales - salvo que no tiene final, porque los otros hombres, que no somos leales tal vez, pero que nunca perderemos de todo la esperanza de serlo, seguiremos honrándolos con palabras' ( $O C$, p. 323). Borges's open-ended conclusion, which consists of the telling and retelling of a story of infamy, derives its power in large measure from our recognition that we share in the events told: that we too are marked by the story much as Kotsuké no Suké was.

${ }^{10}$ Scars function as central motifs in the two stories discussed here, 'El incivil Maestro de Ceremonias' and 'La torma de la espada'. A scar is also important in the portrait of Richard Burton in an essay on the transiaturs of the A rabian. Nights, which opens with the sentence: En Trieste, en 1872 , cn un palacio con
estatuas humedas y obras de salubridad deficientes, un caballero con la cara historiada por una cicatriz atricana - el capitán Richard Francis Burton, consul ingles - emprendio una famosa traducción. (OC, P. 397).

A. B.F. Mitford, Tales of Old Japan (London, 1906), p. 8.

12 For further comments on the use of nubricar, see Molloy, Las letras de Borges, p. 70.
In a story central to the present argument, 'La forma de la espada' (1942), the scar provides the title, the first sentence, the leitmotiv, and the enigma of the story, and is essential for the final recognition and reversal. In this story, the so-called 'Inglés de La Colorada', whom the narrator (named Borges in the story) visits at his ranch in Uruguay, has a grisly scar reaching from his temple to his mouth in a half-moon shape, as we are informed in the first sentence: 'Le cruzaba la cara una cicatriz rencorosa: un arco ceniciento y casi perfecto que de un lado ajaba la sien y del otro el pómulo' (OC, p. 491). The story the scarred man tells of his youth in Ireland revolves around a traitor to the Irish cause, John Vincent Moon, and the events in a house full of scimitars shaped like half-moons. The so-called Englishman's story ends as he takes one of the scimitars and wounds the traitor on the cheek (with Borges again employing the verb rubricar): 'Con esa media luna de acero le rubriqué en la cara, para siempre, una media luna de sangre' (pp. 494-95). A moment later he reveals what the reader already suspects: that he is himself the traitor John Vincent Moon, as shown by the 'cicatriz que me afrenta' (p. 494), a neat play on words which refers both to the locus of the scar, the 'frente' or forchead, and to the scar as sign of his infamy. The story ends with Moon's words: ' $N$ No ve que llevo escrita en la cara la marca de mi infamia? Le he narrado la historia de este modo para que usted la oyerat hasta el fin. Yo he denunciado al hombre que me amparó: yo soy Vincent Moon. Ahora desprécieme' (p. 495).

Mary Louise Pratt has studied this story as an example of a narrative that violates one of the basic conventions of discourse: that narrators are truthful about their identities. She states that the Irishman, in order to tell his story,

feels he must place it in jeopardy by misleading the listener. . . Both the violation and the flouting [of the convention that the narrator does not lie] are perceptible only because we hase the contextual intormation that the Irishman has a scar, and we set this intormation only the contextual intormation that the Irishman has a scar, and we get this information ony
because we get the story secondhand. On its own, the Irishman's story is a perfectly felicitous narrative of personal experience and bears no sign of the lie. ${ }^{13}$

The story of the scar is told as a story of heroism and treachery by one who assumes the position of the hero, but is set within a story, narrated by Borges as narrator, in which the treachery changes sign, and in which the scar, the 'mark of my infamy', serves not only to prove Moon's identity but also to reverse the identity he assumed when telling his story. The scar is overdetermined in the whole of the story: it is the shape of a half-moon, which is also the shape of the sword that carved it in the face of a character who is named Moon. Even so, it remains ambiguous. The most we can say as we read is that the scar is a sign of past violence, but the specifics of that act of violence become clear only as the story comes to its close.

Moon says at the end that he had to tell the story from the hero's point of view for it to be heard. The story is audible or legible only when told by one who can be assumed to tell the truth, which a trator camot be. Vet the reader may not be persuaded of the complete reversal, since there is a greater anbiguity than is immediately apparent. Such an ambiguity is found in the Borges story "Tema det traidor y del heroe', in which Kilparrick, to purge his treachery and serve the lrish cause, is condemned to die a hero's death. Paradoxically, then, he is both hero and uator. Similarly, the end of another story, Los teologos", reveals that para l.t insondable divinidad, [Aureliano] y Juan de Panonid (el ortudoso y al hereje, al

"Tourds a Speech Aat Theory of Literary Discourse (Bloomington, Indiana, 1977), p. 19, 

aborfecedor y el aborrecido, el acusador y la victima) formaban una sola persona'
$\left(O C, \mathrm{p} .55^{6}\right)$.

For Borges, to tell a story is to assume a persona: thus, when Zaid impersonates his cousin Abenjacán he was Abenjacán (OC, p. 606), and Pierre Menard finds it casier (and therefore less interesting) to rewrite Don Quixole by becoming Cervantes than it is when he remains himself $(O C, \mathrm{p} .447)$. Along the same lines, the John Vincent Moon who impersonates the friend he betrayed when he tells his story is that heroic figure for the duration of the story, and the final reversal cannot be complete. Moon closes his tale by telling Borges that he betrayed his friend and protector, and asks to be repudiated by his lisitener. Yct most readers are likely to feel admiration for Moon's ingenuity in telling the story as well perhaps as embarrassment for having been taken in. Moon has earlier committed an act of moral chicanery, telling the story of his scar to persuade the original ow'ner of ' $\mathrm{La}$ Coluradia' 10 sell the ranch to him $(O C, p .+91) .{ }^{44}$ Stories of heroism and treachery are sobering precisely because of the moral ambiguity they reveal not only in the characters but in us as readers. ${ }^{15}$

'La forma de la espada' is made up of a very few elements: two characters, a weapon, two countries, friendship and treachery. In the frame tale, Borges (an Argentine) is forced by adverse weather to stop at the Irishman's house in Uruguay. His host's hospitality is compromised when the visitor asks to be told the story of the scar, which the Irishman will tell only on condition that he be allowed to tell it in a waj that will leave its horror complete. In the frame tale, then, there is a conflict be-tween hospitality and truthfulness. Friendliness is possible only when the relation between Borges and Moon is superficial, and when underlying enigmas are lefi undisturbed. Borges's demand for truthfuluess, however, leads to the revelation of Moon's past treachery, and forces a new act of ireachery: namely', Moon's lie about his own identity. Similarly, Moon's tale reveals that the superficial friendship berwern the two members of the Irish revolutionary group masked ont: of the most terrible of human crimes: betrayal of a firend and companion. The I rish story has lefi a mark on the narrator's face; in the frame tale the same mark becomes the sign of infamy and ereachery, not only at the level of the events narrated but also at that of
the narration itself.

The Irish story acquires a new meaning from the place and the circunstances in which it is retold. In British literature (I have instanced Stevenson) (he scar is a literany device. In the culture of the River l'late countries, however, it is a cultural 'S Similarls, in 'Abenjacin el Bojari', Zaid buys Rector Allaby's silence by telling him his story
(oc(ip.ool).

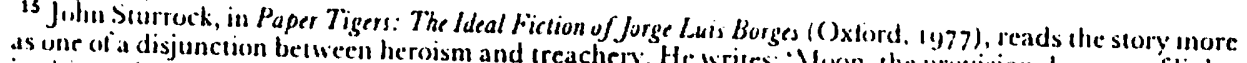
is une of a disjunction between heroism and treachery. He writes: 'Mluon, the provisional source of tighe

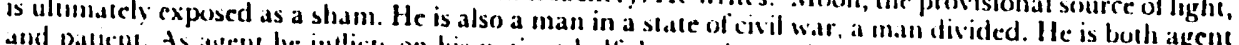

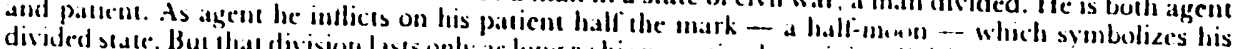
divided seate. Bun flat division lasts only as long as his narration lasts, it is a division fiorced onbolizes his

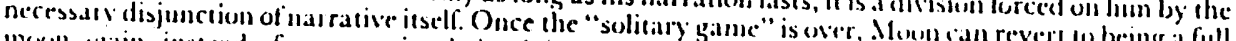

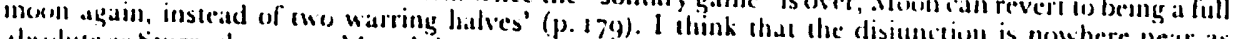

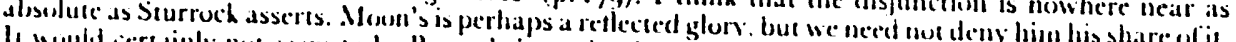

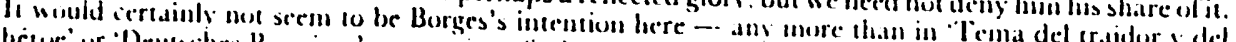

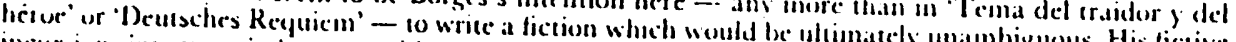

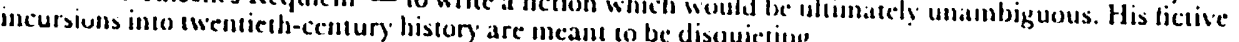

mark of great importance. ${ }^{16}$ In his appropriation of the Irish story, Burges endows it with a rnore specific and historically-grounded reading of Moon's scar.

In fiacundo, the 1845 work which analyses Argentine socicty through the character of the gaucho, Domingo Faustino Sarmicnto notes that when a gaucho challenges a rival to a knife-fight, he seeks not to kill but mark his opponent:

Ej gaucho, a la par de jinete, hace alarde de valiente, y el cuchillo brilla a cada momento, describiendo círculos en el aire, a la menor provocación, sin provecación alguna, sin otro interés que medirse con un desconocido, juega a las puñaladias cono jugaria a less dados... El hombre de la plebe de los demás paises toma el cuchillos para matar, $;$ matta; $\mathrm{el}$ gaucho argentino lo desenvaina para pelear, y hiere solamente. Lis preciso que esti muy borracho, es preciso que tenga instintos verdaderamente malos o rencores nuy profundos, para que atente

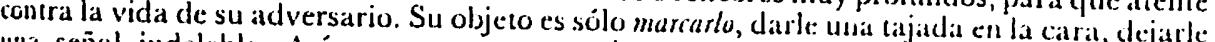
uara señal indeleble. Así se ve a estos gauchos llenos de cicatuices, que rara vez son
profundas. ${ }^{7}$

To kill is a misfortune ('desgracia'), to mark is a triumph. Sarmicnto also declares: "Si sucede alguna desgracia, las simpatias están por el que se desgracio" (p. Gg). The Liller suffers the misfortune and is the tragic hero.

Thirty years later, in José Hernaindez's Martin Fierro (1872), he heru kills a black man early in the poem. Because of the fame of this incident, he becomes known as a Inife fighter. In the poem's second part (1879), only with some difficulty' does he sroid fighting the man's younger brother, who challengres him to a song contest and, implicilly, to a fight. Although he has never been wounded in a fight, Fierro (whose ery name refers to the iron of the knife) is very much a marked man, marked, in cllict, by the success of the poem itself.

Evaristo Carriego, a poet of the then modest Bucnos Aires neighbourhood of Palermo in the early years of this century (who later became the subject of a beoklength essay by Borges, published in 1930), has a poem about the figure of the mighbourhood thug, '1:1 guapo'. Carriego write's:

Le cruzan el rostro, de estigmass violentos,

liondas cicalrices, y quizais le: haldy'ti

llevar imborrable's adornos sangrientos:

caprichos de hembra que tuvo la daga.

La esquina o el patio, de alegres reuniunes,

le oye contar hechos que nadic le niega:

icon una guitarra de altivas canciones

él es Juan Moreira, y él es Santos Vega!

The scars are again a sign that the thug or compadrito has lived the violent life he wells of. but Carriego ironically keeps silent about whether the thug actually committed the deeds he relates. ${ }^{19}$ No one denies his stories to his face: 10 do so would be 11 provoke him to a fight, and perhaps be marked in turn.

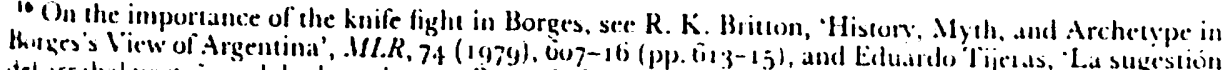

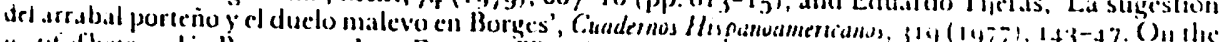

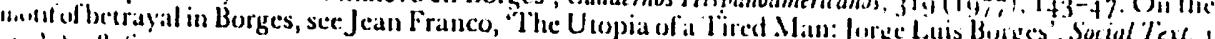
i, $1,1+1,58-6,3,7: 2-7 j$.

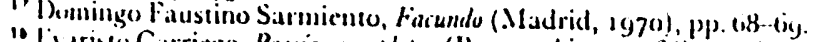

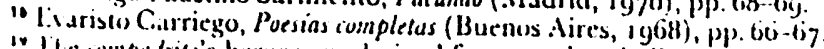

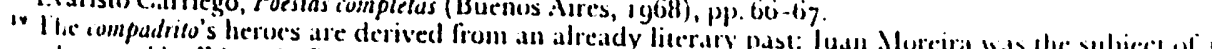

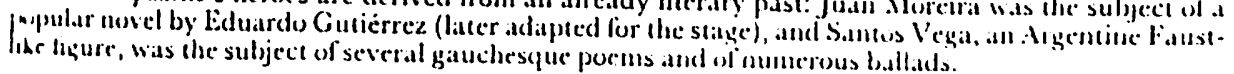


Borges has written numerous poems about knife fights, poems which seem to summon up the violence of the vanished compadritos and cuchilleros who inhabited the Buenos Aires of his boyhood. In one poem about Juan Muraña, another well-known knife fighter from turn-of-the-century Palermo, Borges reduces the identity and memory of Murana to that of his knife:

El cuchillo. La cara se ha borrado.

$Y$ de aquel mercenario cuyo austero

Oficio era el coraje, no ha quedado

Más que una sombra y un fulgor de acero.

Que el tiempo, que los mármoles empaña,

Salve este firme nombre, Juan Muraña.

$$
(O C, \mathrm{p} .827)^{20}
$$

And the poem 'El tango' ( $\left.195^{8}\right)$, an evocation of the rough Buenos Aires underworld from which the dance emerged, ends:

$$
\begin{aligned}
& \text {... El tango crea un turbio } \\
& \text { Pasado irreal que de algún modo es cierto, } \\
& \text { E.l recuerdo imposible de haber muerto } \\
& \text { Peleando, en una esquina de suburbio. }
\end{aligned}
$$

$$
\text { (OC, p. 88g) }
$$

The ending of this poem recalls that of the story ' $\mathrm{El}$ Sur' (1953), in which the character Dahlmann dies in a knife fight or dreams on the operating table that he is dying in a knife fight, the death he in any case would have chosen:

Sintio, al atravesar el umbral, que morir ell una pelea a cuchillo, a cielo abierto y acometiendo, hubiera sido una liberación para él, una feliciclad y una fiesta, en la primera noche del sanatorio, cuando le clavaron la aguja. Sintio que si el, contonces, hubiera podido elegir o soñar su muerte, ésta es la muerte que hubiera elegido o soñado. $(O C, p .530)$

In 'Li Sur' the character prefers to die in a knife fight, and would even have the mark on his forchead (actually the mark of life in a modern city, since he wounded himself climbing a staircasc) be remembered as the mark of the wad of paper thrown at him by the gaucho who provoked him to fight. Similarly', in 'El tango' Borges states that the music and violent /yrics of the tango create an imaginary past in which he, sedentary writer turned man of action, died as knife fighter. The violence of the Argentine past leaves its mark on his imagination and on his text. W'riting himself and his readers into the place of the victim, he reverses the lopos inherited from Sarmiento, for whom the killer is the tragic hero, assured of sympathy in his 'misfortune', a view also expressed in .Martin Fierro. For Borges, on the other hand, to tell - or to hear - one of these violent tales is to be marked by it.

The scar on Mloon's face demands to be explained, but thuse who succumb to impertinent curiosity are duly rewarded, as they too find themselves marked by his intimy. The previous owner of the ranch, 'La Colorada', sold it and thed the scene after hearing Mloon's story. ${ }^{21}$ Borges cast himsell as a character in his narrative to

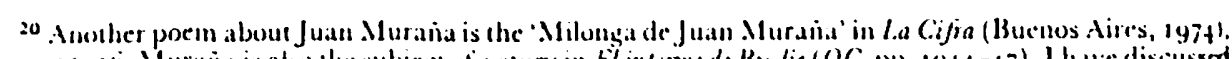

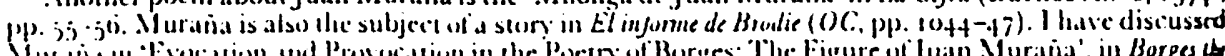

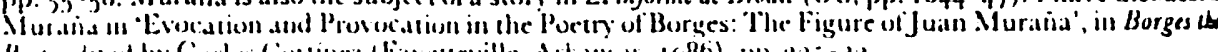

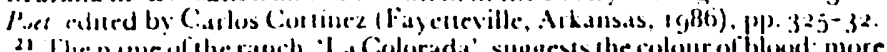

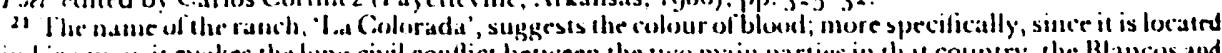

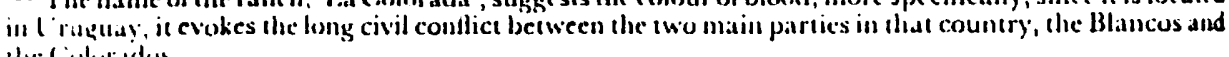
line cioludadus. suggest that each retelling will produce another fearful recognition. In their powerful brevity Borges's stories embody the paralysing violence which is so often their subject. Borges suggests in his essay 'Magias parciales del Quijole' that the technique of fictions within fictions, like the play within the play in Hamlet, owes its efficacy to the fact that we, too, as readers or spectators, are ensnared in the conflicts ne intend to observe at a distance $(O C, \mathrm{p}$. 669). In ' $L$ a forma de la espada' the fiction within the fiction is the thing that catches at our conscience, that makes us aware of our complicity.

Far from being an empty or conventional literary sign, facial scars in Borges (as well as in his admired Stevenson) take on an added meaning of treachery and untrigue. Starting from broad principles of the litcrary function of details, Borges comes to develop the meaning of the sign of the facial scar within the specific context of an Argentine literary tradition, in which being marked signifies loss or defeat. The sar, representing a fundamental ambiguity in fiction, becomes in Burges a mark on writer and reader of fantasized violence. Scars, the marks left by the past, are signs that constitute a coded language that evokes untold stories of violence and betrayal, and at the same time inscribes those stories within the ethos of the Argentine knife gighter.

TLLANE UNIVERSITY

DaNiel. Bat.dekstron 